\title{
PEMANFAATAN HERBA KEMANGI (Ocimum basilicum L.) SEBAGAI ANTIOKSIDAN DALAM SEDIAAN TABLET DAN MASKER GEL
}

\author{
Erni Rustiani ${ }^{1}$, Almasyhuri ${ }^{2}$, Sekar Peny Ningtyas ${ }^{3}$, Devi Fiebrilia ${ }^{4}$ \\ ${ }^{1,3,4)}$ Program Studi Farmasi FMIPA Universitas Pakuan, Bogor \\ ${ }^{2)}$ Pusat Biomedis dan Teknologi Dasar Kesehatan, KeMenKes
}

\begin{abstract}
ABSTRAK
Herba Kemangi dikenal berkhasiat sebagai antioksidan, namun pemanfaatannya masih terbatas. Tujuan penelitian ini adalah membuat formulasi tablet dari ekstrak kering kemangi menggunakan pengikat amilum manihot(alami) dan Polyvinylpirilidone/ PVP (sintetik), membuat formulasi masker gel dari minyak atsiri kemangi menggunakan berbagai konsentrasi karbomer, dan menguji aktivitas antioksidan dalam ekstrak kering dan minyak atsiri kemangi. Pembuatan ekstrak kering kemangi dilakukan dengan metode sokletasi dalam etanol $50 \%$ dan selanjutnya di keringkan denga alat freeze dryer. Sedangkan minyak atsiri daun kemangi dihasilkan dengan metode destilasi uap air.Hasil uji antioksidan ekstrak kering kemangi menunjukkan $\mathrm{IC}_{50}$ sebesar 54,43 ppm dan minyak atsiri kemangi sebesar 454,427 ppm. Kandungan eugenol dalam minyak atsiri adalah 1,76\%. Sediaan tablet dibuat sebanyak 3 formula dengan variasi konsentrasi pengikat yaitu PVP 5\%(FI), amilum manihot 10\% (FII) dan kombinasi PVP : amilum manihot (2\% : $10 \%$, FIII). Hasil pengujian mutu tablet( keseragaman ukuran, keseragaman bobot, kekerasan dan waktu hancur) untuk FI hampir sama dengan FIII. Sediaan masker gel dibuat sebanyak 3 formula dengan variasi konsentrasi karbomer yaitu 0,5\% (FI), $0,75 \%$ (FII) dan $1 \%$ (FIII). Hasil pengujian mutu masker gel (organoleptik, pH, dan viskositas) untuk semua formula baik dan yangmemiliki aktivitas antioksidan paling kuat adalah Formula II dengan jumlah karbomer 0,75 \%.
\end{abstract}

Kata kunci : Kemangi (Ocimum basilicum L.), tablet, masker gel, antioksidan

\section{PENDAHULUAN}

Masyarakat umumnya mengenal kemangi sebagai sayuran yang dapat dimakan segar sebagai lalapan dengan cara memakan atau mengunyah secara langsung karena aroma wangi dari kemangi sendiri mengundang selera makan. Menurut Penelitian Endang Hadipoentyanti (2008), bahwa kemangi (Ocimum basillicum L.) mengandung eugenol sebesar $46 \%$. Kandungan eugenol dalam kemangi ini berperan sebagai antioksidan, yang dapat menetralkan radikal bebas, sehingga kemangi ada manfaatnya di bidang obat dan kosmetik.Begitu pula Ramesh dan Satakopan (2010) menyatakan bahwa kemangi memiliki kemampuan sebagai antioksidan, sehingga perlu dikembangkan bentuk sediaan inovasi baru yaitu dibuat sediaan tablet dan masker gel.

Inovasi baru dalam bentuk tablet diharapkan akan lebih disukai, karena banyak keuntungan dalam pemakaian. Beberapa keuntungan tablet adalah mengandung dosis zat aktif yang tepat dan teliti, kemudahan tranportasi dari pada sediaan cair dan beberapa obat lebih stabil dalam bentuk tablet. Banyak obat yang beredar dalam bentuk tablet dan 90\% obat untuk efek sistemik diberikan melalui oral (Lachman, 1994).Penggunaan bahan pengikat sintetik dalam sediaan tablet membuat harga obat semakin mahal, terutama bila menggunakan bahan tambahan sintetik seperti PVP.Sehingga perlu dilakukan 
pengolahan bahan-bahan alam, salah satunya yaitu amilum manihot sebagai bahan pengikat tablet.

Kemangi yang disuling dan diambil minyak atsirinya dapat dipakai sebagai bahan perawatan wajah dalam bentuk masker.Bentuk sediaan masker gel memiliki kelebihan dibandingkan dengan krim atau losion, yaitu memberikan rasa dingin dan kesegaran pada kulit kering. Proses pelepasan bahan aktif pada sediaan masker gel ini sangat bagus. Bahan aktif dapat dilepaskan dalam waktu singkat dari pembawanya dan biasanya kotoran atau kulit ari yang telah mati akan ikut terangkat (Reynold, 1982).Zat aktif pada masker dapat lebih lama berinteraksi dengan kulit wajah sehingga dapat mengembalikan kelembutan kulit dan dengan pemakaian teratur dapat mengurangi kerutan halus pada kulit wajah.

Berdasarkan latar belakang tersebut maka penelitian ini dilakukan untuk membandingkan mutu tablet herba kemangi yang dibuat menggunakan amilum manihot dan Polyvinylpyrrolidone (PVP), membuat masker gel dengan berbagai variasi karbomer serta menganalisis aktivitas antioksidan dalam ekstrak kering, sediaan tablet dan masker gel.

\section{METODE PENELITIAN Bahan}

Herba kemangi (Ocimum basilicum L), etanol 50\%, metanol, PVP, amilum manihot, perfiller $\mathrm{PH}$ 101, talk, $\mathrm{Mg}$ stearat, karbomer, trietanolamin (TEA), polietilen glikol 6000 (PEG 6000), gliserin, etanol $96 \%$, natriummetabisulfit, dinatrium EDTA ( $\mathrm{Na}_{2}$ EDTA), metil paraben, propil paraben,akuades, 1,1difenil-2-pikrilhidrazil (DPPH), vitamin C, larutan dapar $\mathrm{pH} 4$ dan $\mathrm{pH} 7$.

\section{Alat}

Alat - alat yang digunakan meliputi neraca analitik (Mettler Toledo), corong, cawan krus, oven (Memmert), tanur
(Vulcan A550), moisture balance(ANDMX-50),flowtester (lokal), freeze dryer(Scanvac-coolsave), alat sokletasi, alat destilasi,Spektrofotometer UV-Vis (Optizen), Gas Chromatography (GC), kain penyaring, stopwatch, ayakan dengan berbagai ukuran serta alat-alat gelas, homogenizer(IKA $\mathrm{RW}$ ), viskometer(Brookfield), $\mathrm{pH}$ meter (Hanna), dan alat gelas lainnya.

\section{Pembuatan Ekstrak Kering Kemangi}

Kemangi dibersihkan dari kotoran yang menempel, kemudian dicuci bersih dengan air yang mengalir dan dioven dengan suhu $40-50^{\circ} \mathrm{C}$ sampai kering selama \pm 3 hari.Setelah kering digrinder dan diayak menggunakan mesh 30 (DepKes RI, 1985).

Ekstrak dibuat dengan cara sokletasi di dalam alat sokletasi. Ekstraksi dilakukan dengan etanol $50 \%$.Serbuk simplisia kemangi yang digunakan sebanyak 400 gram.Dimasukkan kedalam alat sokletasi yang sudah dirangkai sesuai dengan kapasitas alat sampai serbuk habis digunakan, lalu direndam dengan etanol $50 \%$ selama 24 jam.Etanol yang digunakan sebanyak 4 Liter.Setelah dilakukan perendaman selama 24 jam kemudian dinyalakan alat sokletasi, hingga diperoleh ekstrak cair. Ekstrak cair kemudian di freeze dry sehingga diperoleh ekstrak kering kemangi.Selanjutnya dilakukan penetapan kadar air, kadar abu dan rendemen simplisia.

\section{Pembuatan Minyak Atsiri Kemangi}

Daun kemangi segardikumpulkan sebanyak 36 kg.Dilakukan sortasi basah.Dicuci dengan air sampai bersih.Kemudian ditiriskan sampai tidak tersisa air.Daun yang sudah tiris dianginanginkan selama 1-2 jam.Pembuatan minyak atsiri daun kemangi dilakukan dengan menggunakan metode destilasi uap air. Simplisia kemangi dimasukkan kedalam piringan yang dibawahnya telah 
diisi dengan air mendidih, uap air yang keluar melalui lubang-lubang piringan akan mengalir dan menembus sela-sela dari simplisia, dengan adanya uap air ini minyak atsiri akan terekstraksi dan terbawa, kemudian uap air dan minyak atsiri yang terbentuk dialirkan melalui pipa dan selanjutnya akan dialirkan kedalam sistem pendingin balik dan akan terkondensasi menjadi air dan minyak. Campuran dari air dan minyak ini ditampung dalam sebuah wadah pemisah cairan. Karena perbedaan berat jenis maka air dan minyak atsiri akan terpisah, air berada dibawah permukaan minyak atsiri dan sebaliknya. Minyak atsiri yang diperoleh ditampung dalam wadah atau botol yang tidak tembus cahaya dan disimpan ditempat yang sejuk agar tidak terjadi oksidasi. Selanjutnya dilakukan analisis minyak atsiri ini menggunakan metode Gas Chromatography (GC). Untuk mengetahui senyawa eugenol serta kadarnya.

Formulasi Dan Pembuatantablet Ekstrak Keringkemangi

Tiap tablet mempunyai berat $500 \mathrm{mg}$, dengan formulasi terdapat di Tabel 1.

Tabel 1.Formulasi Tablet Ekstrak Kemangi

\begin{tabular}{|c|c|c|c|}
\hline Bahan & FI & FII & FIII \\
\hline Ekstrak Kering Kemangi & $226 \mathrm{mg}$ & $226 \mathrm{mg}$ & $226 \mathrm{mg}$ \\
\hline Amilum Manihot & 0 & $10 \%$ & $5 \%$ \\
\hline PVP K30 & $5 \%$ & 0 & $2 \%$ \\
\hline Perfiller PH 101 & $15 \%$ & $15 \%$ & $15 \%$ \\
\hline Talk & $2 \%$ & $2 \%$ & $2 \%$ \\
\hline Mg Stearat & $1 \%$ & $1 \%$ & $1 \%$ \\
\hline Laktosa ditambahkan hingga & $100 \%$ & $100 \%$ & $100 \%$ \\
\hline
\end{tabular}

Serbuk ekstrak kering kemangi, laktosa dan perfiller PH 101 sebanyak $10 \%$, masing-masing diayak dengan menggunakan mesh 30, kemudian dimasukkan ke dalam wadah laludiaduk hingga homogen kira-kira 5 menit. Ditambahkan larutan pengikat PVP K30, aduk hingga menjadi massa yang kompak. Bila perlu dapat ditambahkan air hangat. Massa yang basah kemudian diayak mesh 8 hingga terbentuk granul basah, dikeringkan di dalam lemari pengering yang dialasi kain batis pada suhu $40-50^{\circ} \mathrm{C}$ semalaman hingga terbentuk granul kering.Granul kering kemudian diayak dengan menggunakan ayakan mesh 10, lalu dimasukkan kedalam kantong plastik, ditambahkan kedalamnya perfiller $\mathrm{PH} 101$ sebanyak $5 \%$, talk dan magnesium stearat yang telah diayak dengan menggunakan mesh 30, kemudian dikocok dalam kantong plastik selama 5 menit hingga didapatkan massa siap cetak. 
Formulasi dan Pembuatan Masker Gel Kemangi

Tabel 2. Formulasi Masker Gel Kemangi

\begin{tabular}{|c|c|c|c|c|}
\hline \multirow{2}{*}{ Bahan } & \multicolumn{4}{|c|}{ Formula Ke- (dalam \%) } \\
\hline & I & II & III & IV \\
\hline Minyak atsiri daun kemangi & 4 & 4 & 4 & - \\
\hline Karbomer & 0,5 & 0,75 & 1 & 0,75 \\
\hline TEA & 1 & 1 & 1 & 1 \\
\hline PEG 6000 & 10 & 10 & 10 & 10 \\
\hline Gliserin & 10 & 10 & 10 & 10 \\
\hline Etanol 96\% & 20 & 20 & 20 & 20 \\
\hline Natrium Metabisulfit & 0,03 & 0,03 & 0,03 & 0,03 \\
\hline $\mathrm{Na}_{2}$ EDTA & 0,05 & 0,05 & 0,05 & 0,05 \\
\hline Metil Paraben (Nipagin) & 0,03 & 0,03 & 0,03 & 0,03 \\
\hline Propil Paraben (Nipasol) & 0,01 & 0,01 & 0,01 & 0,01 \\
\hline Akuades ditambahkan hingga & 100 & 100 & 100 & 100 \\
\hline $\begin{array}{l}\text { Karbomerdikembangkan } \\
\text { air panas dan dimasukkan gliser } \\
\text { demi sedikit kemudian tambah } \\
\text { hingga mengembang (campuran } \\
\text { paraben dan propil paraben } \\
\text { dalam etanol } 96 \% \text { (camp } \\
\text { Campuran 1 dan camp } \\
\text { dihomogenkan dengan dipanask }\end{array}$ & 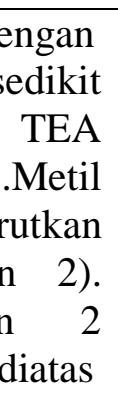 & $\begin{array}{l}\text { masukan } \\
\mathrm{Na}_{2} \mathrm{EDTA} \\
\mathrm{PEG} 600 \\
\text { masukan } \\
\text { Dimasukk } \\
\text { kedalam } \\
\text { dengan h } \\
300 \mathrm{rpm} \mathrm{s}\end{array}$ & $\begin{array}{l}\text { Natrium } \\
\text { yang dila } \\
\text { dilarutka } \\
\text { kedala } \\
\text { minyak } \\
\text { camp } \\
\text { mogenizer } \\
\text { lama } 10 \mathrm{me}\end{array}$ & $\begin{array}{l}\text { metabisulfit dan } \\
\text { utkan dengan air. } \\
\text { n dalam air dan } \\
\text { m campuran. } \\
\text { itsiri daun kemangi } \\
\text { Iran.Dihomogenkan } \\
\text { dengan kecepatan } \\
\text { nit. }\end{array}$ \\
\hline
\end{tabular}

penangas air pada suhu $80^{\circ} \mathrm{C}$ lalu

\section{HASIL DAN PEMBAHASAN}

Hasil Pembuatan Ekstrak Kering dan Minyak Atsiri Kemangi

Serbuk simplisia sebanyak 400 gram di ekstraksi dengan metode sokletasi menggunakan pelarut etanol $50 \%$, diperoleh ekstrak cair sebanyak 4 L, kemudian di freeze dry dan didapat hasil sebanyak 443 gram (telah ditambah maltodekstrin), dengan rendemen 10,75\%. Hasil kadar air 4,66\% dan kadar abu $1,295 \%$. Hasil tersebut memenuhi persyaratan kadar air $<5 \%$ dan kadar abu $<13 \%$ (DepKes, 2000). Hasil uji fitokimia dilakukan untuk melihat kandungan senyawa yang terdapat didalam tanaman tersebut.Hasil menunjukkan ekstrak kering kemangi mengandung alkaloid, flavonoid, saponin, dan tanin.

Hasil minyak atsiri yang didapatkan dari $35 \mathrm{~kg}$ daun kemangi sebanyak $35 \mathrm{ml}$ dengan berat 32,37 gram, rendemen yang didapat adalah 0,1\% dengan berat jenis 0,925 . Minyak atsiri yang dihasilkan berwarna kuning kecoklatan dan berbau khas aromatik kuat.

\section{PenentuanAktivitasAntioksidan \\ Ekstrak Kering dan Minyak Atsiri Kemangi}

Penentuan aktivitas antioksidan dilakukan dengan menggunakan metode DPPH. Panjang gelombang maksimum yang didapat sebesar $516 \mathrm{~nm}$. Sedangkan waktu inkubasi optimum yang didapat yaitu selama 30 menit. Vitamin C digunakan sebagai kontrol positif karena vitamin C merupakan salah satu vitamin yang berpotensi sebagai antioksidan dengan nilai $\mathrm{IC}_{50}$ sebesar 4,82 ppm. Aktivitas antioksidan ekstrak kemangi dengan menggunakan konsentrasi yang sama dengan vitamin $\mathrm{C}$ didapatkan nilai $\mathrm{IC}_{50}$ sebesar 54,43 ppm (aktif) dengan kelinearan 0,998.Besar IC50 yang didapat untuk minyak atsiri sebesar 454,427 ppm termasuk golongan antioksidan kurang aktif. 


\section{Hasil Analisis Minyak Atsiri Kemangi}

Berdasarkan hasil analisis GC minyak atsiri daun kemangi mengandung senyawa eugenol sebesar $1,76 \%$. Hasil ini cukup rendah sehingga potensi eugenol sebagai antioksidannya juga rendah, karena berdasarkan jurnal penelitian sebelumnya kandungan eugenol dalam daun kemangi (Ocimum basillicum L.) sebesar $46 \%$.

\section{Hasil Evaluasi Tablet Ekstrak Kemangi \\ Hasil dari penampilan semua} formula tablet ekstrak kemangi rata-rata sama, mempunyai bentuk bundar, cetakan polos, berwarna hijau bercak putih. Hasil dapat dilihat pada Gambar 1.

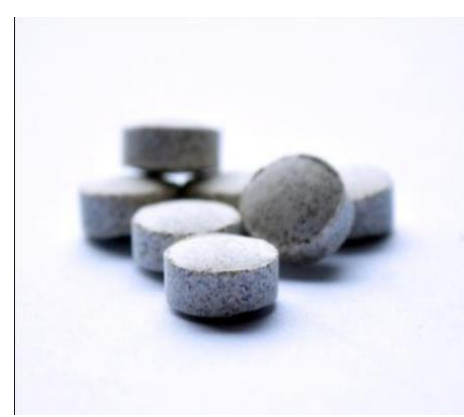

A

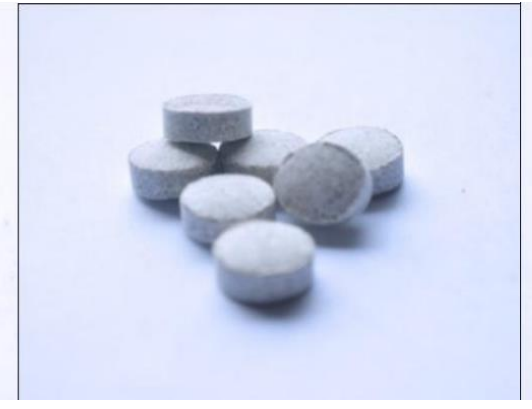

B

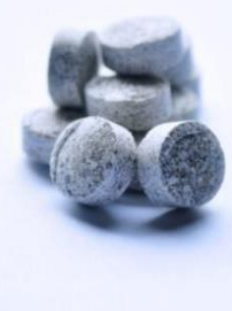

C

Gambar 1.Tablet Ekstrak Kering Kemangi Formula I (A), II (B), III (C)

Hasil pengujian mutu tablet meliputi keseragaman ukuran, keseragaman bobot, kekerasan, friabilitas dan waktu hancur. Hasil terdapat di Tabel 3.

Tabel 3.Hasil Pengujian Keseragaman Ukuran, Keseragaman Bobot, Kekerasan, Friabilitas dan Waktu Hancur

\begin{tabular}{|c|c|c|c|c|c|c|c|}
\hline Formula & $\begin{array}{c}\text { Rata - Rata } \\
(\text { Diameter })\end{array}$ & $\begin{array}{c}\text { Tebal } \\
(\mathbf{c m})\end{array}$ & $\begin{array}{c}\text { Rata- } \\
\text { Rata } \\
(\mathbf{c m})\end{array}$ & $\begin{array}{c}\text { Range } \\
(\mathbf{m g})\end{array}$ & $\begin{array}{c}\text { Rata-Rata } \\
\text { kekerasan(k } \\
\mathbf{p})\end{array}$ & $\begin{array}{c}\text { Friabilitas } \\
(\boldsymbol{\%})\end{array}$ & $\begin{array}{c}\text { Waktu } \\
\text { Hancur }\end{array}$ \\
\hline I & 1,01 & 0,57 & 511,74 & $503,7-$ & 7,14 & 2,87 & 12 menit 11 \\
& & & & 520,4 & & & detik \\
\hline II & 1,01 & 0,57 & 515,32 & $\begin{array}{c}509,7- \\
522,6\end{array}$ & 5,7 & 1,90 & 8 menit 54 \\
& & & & 510,57 & 7,16 & 2,55 & 12 menit 20 \\
III & 1,01 & 0,57 & 510,5 & & detik \\
\hline
\end{tabular}

Persyaratan keseragaman ukuran yaitu diameter tablet tidak kurang dari 1 $1 / 3$ kali dan tidak lebih dari 3 kali tebal tablet.Hasil memenuhi syarat. Persyaratan Farmakope Indonesia Edisi III untuk keseragaman bobot adalah tidak lebih dari 2 tablet yang mempunyai penyimpangan lebih dari $5 \%$ dan tidak lebih dari 1 tablet yang mempunyai penyimpangan lebih dari $10 \%$ dari bobot rata-rata hasil pengujian. Hasil memenuhi syarat. Kekerasan tablet menunjukan bahwa semua formula memenuhi pesyaratan yaitu minimal 4 Kp. Hasil evaluasi friabilitas pada semua tablet tidak memenuhi persyaratan, hal ini dikarenakan punch yang tidak rata sehingga tablet yang dihasilkan bergerigi. 
Bentuk tablet tersebut akan mempengaruhi friabilita tablet. Hasil evaluasi waktu hancur pada FI 12 menit 11 detik, FII 8 menit 54 detik, dan FIII 12 menit 20 detik. Semua formula memenuhi persyaratan yaitu kurang dari 15 menit.

\section{Uji Aktifvitas Antioksidan Tablet Ekstrak Kemangi}

Aktivitas antioksidan tablet $\mathrm{IC}_{50}$ pada FI 89,02 ppm, FII 93,35 ppm, dan FIII 91,74 ppm. Bila dibandingkan ratarata setiap formula dengan hasil Vitamin C 4,82 ppm adalah mempunyai perbandingan 1 : 25. Kemungkinan terjadi penurunan aktivitas antioksidan dari ekstrak menjadi tablet pada saat proses pembuatan tablet itu sendiri.

\section{Hasil Evaluasi Mutu Sediaan Masker Gel}

Formula IV merupakan masker tanpa zat aktif (plasebo) sebagai pembanding untuk formula I, II dan III. Formula I, II dan III menghasilkan gel yang homogen, berwarna kuning pucat dan berbau aromatik kuat. Warna kuning pucat pada formula I lebih pekat dibandingkan dengan formula II dan III.Karena konsentrasi karbomernya yang paling kecil. Semakin kecil jumlah karbomer pada sediaan maka warna kuningnya semakin pekat. Sedangkan formula IV menghasilkan gel yang homogen, bening dan tidak berbau.Hasil masker gel kemangi terdapat di Gambar 2.

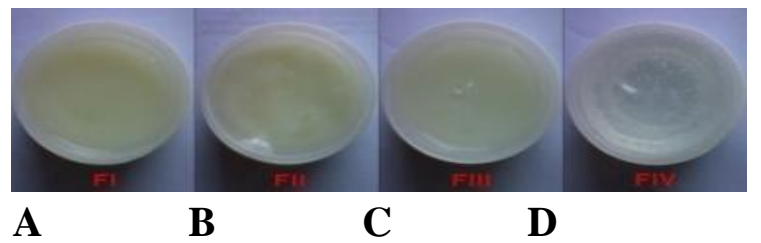

Gambar 2. Masker Gel Kemangi Formula I (A), II (B), III (C), IV (D)

Sediaan gel ini memiliki $\mathrm{pH}$ yang berbeda-beda, untuk fomula dengan jumlah karbomer yang semakin banyak namun jumlah trietanolamin (TEA) yang sama maka $\mathrm{pH}$ yang dihasilkan semakin kecil karena sifat karbomer yang asam. Sedangkan pada sediaan gel plasebo (formula IV) dengan jumlah karbomer yang sama dengan formula II yaitu $0,75 \%$ menghasilkan $\mathrm{pH}$ yang lebih tinggi dibandingkan formula II tersebut, hal ini dikarenakan penambahan zat aktif minyak atsiri kemangi pada formula II yang bersifat asam. Perbedaan konsentrasi karbomer ini dapat dilihat dari perbedaan $\mathrm{pH}$ tersebut.

Pengaruh perbedaan konsentrasi karbomer juga dapat dilihat pada viskositas gel, karena pada formula yang mengandung karbomer lebih banyak maka viskositasnya semakin tinggi. Formula III dengan konsentrasi karbomer
$1 \%$ memiliki viskositas yang paling tinggi dibanding formula I, II, dan IV. Hal tersebut yang menyebabkan penurunan viskositas gel. Data lengkap hasil evaluasi uji mutu sediaan dapat dilihat pada Tabel 4 . 
Fitofarmaka, Vol 3, No. 2, Desember 2013 ISSN: 2087-9164

Tabel 4.Hasil Evaluasi Uji Mutu Sediaan Masker Gel

\begin{tabular}{|c|c|c|c|c|}
\hline Pengamatan & Formula I & Formula II & Formula III & Formula IV \\
\hline Homogenitas & Homogen & Homogen & Homogen & Homogen \\
\hline $\begin{array}{c}\text { Organoleptik } \\
\text {-Bentuk } \\
\text {-Warna } \\
\text {-Bau }\end{array}$ & Agak kental & Kental & Kental & Kental \\
\cline { 2 - 5 } & Kuning Pucat & $\begin{array}{c}\text { Kuning } \\
\text { Pucat }\end{array}$ & $\begin{array}{c}\text { Kuning } \\
\text { Pucat }\end{array}$ & Bening \\
\cline { 2 - 5 } & Aromatik kuat & $\begin{array}{c}\text { Aromatik } \\
\text { kuat }\end{array}$ & $\begin{array}{c}\text { Aromatik } \\
\text { kuat }\end{array}$ & Tidak berbau \\
\hline pH & 7,57 & 7,03 & 6,89 & 7,26 \\
\hline Viskositas & $3090 \mathrm{cps}$ & $16310 \mathrm{cps}$ & $17570 \mathrm{cps}$ & $16450 \mathrm{cps}$ \\
\hline
\end{tabular}

\section{Hasil Pengujian Aktivitas Antioksidan Sediaan Masker Gel}

Setelah dibuat sediaan masker gel aktivitas antioksidannya meningkat dengan penggunaan minyak atsiri sebesar 4\%. Mungkin dikarenakan jumlah minyak yang digunakan besar dan pengaruh dari zat tambahan yang berfungsi sebagai antioksidan juga.Adapun pengaruh sinergis dari zat tambahan ini.Walaupun sebenarnya zat tambahan bersifat inert namun tidak menutup kemungkinan zat tambahan ini mempengaruhi hasil aktivitas antioksidan meningkat.Bila dibandingkan dengan formula IV (plasebo) yang memiliki aktivitas antioksidan yang kurang aktif karena memiliki IC50 945,413 ppm.

Dari hasil yang didapat aktivitas antioksidan tiap formula berbedabeda.Dimana pada formula dengan konsentrasi karbomer yang semakin tinggi aktivitas antioksidannya pun semakin besar.Kemungkinan hal ini karena karbomer mengikat zat aktif lebih banyak.Dan hasil pengukuran pada minggu berikutnya aktivitas ini semakin menurun, hal ini mungkin dipengaruhi oleh suhu penyimpanan yang semakin tinggi dan lamanya penyimpanan sehingga antioksidannya teroksidasi. Namun pada formula IV yaitu sediaan plasebo memiliki aktivitas antioksidan yang sangat rendah karena tidak ada zat aktif.Data IC50 untuk FI (151,96 ppm), FII (149,94 ppm), FIII (150,94 ppm), dan FIV $(945,41 \mathrm{ppm})$.

\section{KESIMPULAN}

1. Mutu tablet dilihat secara keseluruhan yang menggunakan pengikat Polyvinylpirolidone (PVP)dengan konsentrasi 5\% (Formula I) hampir sama dengan campuran pengikat Polyvinylpirolidone (PVP) dengan amilum manihot konsentrasi $2 \%$ : 10\% (Formula III).

2. Aktivitas antioksidan ekstrak kering kemangi sebesar 54,43 ppm (aktif) sedangkan aktivitasantioksidan tablet sebesar 89,02 ppm (Formula I), 93,35 ppm (Formula II), dan 91,74 ppm (Formula III).

3. Semua Formula sediaan masker gel menghasilkan sediaan yang baik bila dilihat dari uji organoleptik $\mathrm{pH}$ dan viskositas, namun yang memiliki aktivitas antioksidan paling kuat adalah Formula II denganjumlahkarbomer $0,75 \%$.

\section{DAFTAR PUSTAKA}

Departemen Kesehatan Republik Indonesia.1985. Formularium Kosmetika Indonesia. Jakarta: Direktorat Jendral Pengawasan Obat dan Makanan.

Departemen Kesehatan Republik Indonesia.2000. Parameter Standar Umum Ekstrak Tumbuhan Obat. Direktorat Pengawasan Obat dan Makanan.Jakarta. 
Fitofarmaka, Vol 3, No. 2, Desember 2013 ISSN: 2087-9164

Departemen Kesehatan Republik Indonesia.1979. Farmakope Indonesia. Edisi III. Direktorat Pengawasan Obat dan Makanan. Jakarta.

Lachman, L., HA.Liebermann., JL. Kanig. 1994. Diterjemahkan oleh Siti Suyatmi. Teori dan Praktek Farmasi Industri. Jilid II. Edisi III. Jakarta : UI Press

Hadipoentyanti E dan wahyuni S. 2008.Keragaman Selasih (Ocimum spp.) berdasarkan karakter morfologi produksi dan mutu herba: Jurnal Litti

Reynold, JEF. 1982. Martindle The Extra Pharmacopoeia. $28^{\text {th }}$ Edition.London : $\quad$ The Pharmaceutical Press.

Ramesh, B. dan Satakopan, V.N. 2010.In Vitro Antioxidant Activitesi Of Ocimum Species : Ocimum Basilicum andSanctum. Journal off cell and Tissue Research Vol. 10(1) : 2145-2150 